UDC 159.923/2

https://doi.org/10.23939/sjs2020.01.160

Aleksandra Kuczyńska-Zonik,

Doctor in political science,

Doctor in humanities in the field of archeology

Head of Department of the Baltics at the Institute of Central Europe, Lublin, Poland,

kuczynska.a@gmail.com

\title{
PROPAGANDA, DISINFORMATION, STRATEGIC COMMUNICATION - HOW TO IMPROVE COOPERATION IN CEE REGION?
}

(C) Kuczyńska-Zonik Aleksandra, 2020

A paper deals with possibilities and opportunities for cooperation in Central and Eastern European region in the field of information security with particular emphasis on media influenced by Russia. My point of departure is that the information threats to societal security is external and they have relevant impact on the sustainability, conditions for evolution, of traditional patterns of language, culture and religious and ethnic identity, custom and values. An information crisis in the Baltic states results from the process of manipulation and disinformation campaign against the Russian-speaking residents. The V4 states including Poland do not display a numerous Russian-speaking audience, thus Russian propaganda here is facilitated by local pro-Russian media. This paper unveils it is necessary to develop effective offensive procedures to fight propaganda in the media and promote democratic values. States should strive to create an open, pluralistic information environment. Such strategies should be realized by both public and private sectors as well as the civil sector so as to cooperate in information complementation and exchange. Dealing with the contemporary challenges should include prevention, community management, social media management, psychosocial support and legal measures. Restoration of confidence in the media and development of professional journalism are essential. Additionally, the lack of new media literacy skills, together with the combination of populism and anti-liberal narratives, will increase its vulnerabilities to more risks than information security.

Key words: information security; disinformation; propaganda; cooperation; Central and Eastern Europe.

Aleksandra Kuczył ska-Zonik

Celem artykułu jest wskazanie możliwości i sposobów wspŁpracy w regionie Europy Środkowo-Wschodniej w zakresie bezpieczeństwa informacyjnego, szczególnie w kontekście wpływu informacyjnego Rosji. Podstawą analizy jest założenie, Łe zagrołenia informacyjne dla bezpieczeństwa społecznego mają charakter zewnętrzny i mają istotny wpływ na trwałość, warunki rozwoju, język, wzorce kulturowe, religijne i etniczne, tożsamość, tradycję i wartości w państwie. Zagrożenia informacyjne w państwah bałtyckich wynikają głŁwnie z manipulacji i kampanii dezinformacyjnych skierowanych do osłb rosyjskojęzycznych. W państwach $\mathrm{V4}$, w tym w Polsce, gdzie brak jest licznych mniejszości rosyjskojęzycznych, propagandŁ rosyjską wspierajŁ lokalne media prorosyjskie. Artykul wskazuje na konieczność opracowania 
skutecznych mechanizmów walki $z$ propagandą $w$ mediach $i$ promowania wartości demokratycznych. Celem państw powinno być tworzenie otwartego, pluralistycznego środowiska informacyjnego. Takie działania powinny być realizowane zarówno przez podmioty publiczne, jak i sector prywatny oraz społeczeństwo obywatelskie, współpracujące w kwestii wymiany informacji. Strategie na rzecz przeciwdzialania dezinformacji powinny obejmować zapobieganie kryzysom, zarządzanie społeczeństwem, zarządzanie mediami społecznościowymi, wsparcie psychospołeczne i Irodki prawne. Niezbędne są odbudowa zaufania do mediów i rozwłj profesjonalnego dziennikarstwa. Brak umiejętności korzystania z nowych mediów, w połŁczeniu $z$ populizmem i narracjami antyliberalnymi, zwiększą podatność spoleczeństwa na inne zagrożenia.

Słowa klucze: bezpieczeństwo informacyjne; dezinformacja; propaganda; współpraca; Europa Środkowo-Wschodnia

Introduction. A paper deals with possibilities and opportunities for cooperation in Central and Eastern European region in the field of information security with particular emphasis on media influenced by Russia. My point of departure is that the information threats to societal security come from outside the state and they have relevant impact on the state security defined by Buzan, such as the sustainability, conditions for evolution, of traditional patterns of language, culture and religious and ethnic identity, custom and values. While currently an information crisis in the Baltic states results from the process of manipulation and disinformation campaign against the Russian-speaking residents, the V4 states including Poland do not display a numerous Russian-speaking audience, thus Russian propaganda here is facilitated by local pro-Russian media. Most of them have been active only since 2014. They claim no allegiance to the Kremlin and it is difficult to prove a link between the propaganda outlets and Russia-based entities. They are characterized by subtle promotion of anti-liberal establishment and traditional conservative values rather than openly pro-Russian agendas. Nevertheless the lack of new media literacy skills, together with the combination of populism and anti-liberal narratives, will increase its vulnerabilities to more risks than information security.

Information security concerns and national strategies. It is nothing new to say that Russian propaganda effectively absorbs the attention of Russian-speaking audiences in the Baltic states, strengthens and sacralizes narratives regarding Russia's position and its interests in the international environment. Since security threats often reach across borders, for Lithuania, Latvia and Estonia the fight against propaganda and disinformation has become one of a security priority. While the information threat is recognized as relevant for each of the Baltic states they have chosen different instruments of taking specific measures within their bounds (FEPS, 2016). Their national strategies include complex efforts that aim at counteracting immediate threats of manipulation as well as create favourable conditions for safeguarding information development. In contrast to Estonia Russian channel named RTR Planet broadcasted in Lithuanian was suspended for a period of 3 months for inciting hatred between the Ukrainian and Russian nations as well as a Russian NTV channel was penalised in the same way for broadcasting false information about the Soviet Army in 1991. Nonetheless, if such restrictions of propaganda are practicable in TV and radio transmissions, it's almost impossible to implement them in social media.

Apart from broadcast prohibitions, censorship and restrictions for Russian journalists, Lithuania, Latvia and Estonia strive to create an open, pluralistic information environment. Media diversity and alternative sources of information are some of the solutions implemented in reaction to information threats. They allow communication content verification and reaching to different media space. Broadcasting in the national language only excludes the Russian-speaking community from the country's media space which makes it necessary to broaden the media platform by introducing public Russian-language media in countries where the Russian minority constitutes a considerable number. While Lithuania and Latvia are considering such a solution, Estonia has already launched the new ETV+ channel (LSM, 2016). Additionally, Lithuania has offered a workshop programme for Russian-speaking journalists with a view to 
create an open, fully-fledged, independent media environment in the Baltic states. However, there are some obstacles. Russian-speaking media outlets can be under pressure either due to financial cuts or links to proRussian business interests. Moreover, public media influence social integrity and so lack of access to public information can cause social exclusion. Russian-language media are still a challenge to national security since radio and TV channels broadcasting in a language other than the official one decrease diaspora mobilization to learn the official language, weaken their integration. Russian-speaking minorities existing in Russian media space feel connected to it, adopt its point of view, ideology and values. This in turn may generate threats to the integrity of the countries of their habitat. The question of access to information for local recipients, members of ethnic and language minorities, is often ignored in the discussions on national security.

While Russian propaganda in the Baltic states is much more effective because of the numerous Russian-speaking audience, Russia's media ability to influence a great number of people in the V4 is rather limited. According to the GLOBSEC Policy Institute's Vulnerability Index, Poland is the least vulnerable country among the V4 countries to subversive Russian influence (Šuplata, Nič, 2016). Thus, the main aim of Russian propaganda is to strengthen social division as well as to deteriorate bilateral relations between Poland and its neighbours. Apart from anti-establishment slogans, such media share anti-American, antiUkrainian, and anti-Lithuanian sentiments in Poland to inspire division within Polish society. For example, the Facebook fan page "The People's Republic of Vilnius" exemplifies revisionist moods supported by the Polish minority in Lithuania. It is characteristic of Russian propaganda in the region to focus mostly on undermining the relations between the country and its neighbours.

To increase its effectiveness, the media message is accompanied by virtual supporters. The message and the medium are mutually reinforcing: "parties, NGOs, media, and Church read the script, and the script makes more sense for being embodied". There are proven diplomatic, economic, organisational and financial links between the institutions, business, and politicians in Russia and the CEE states (Jiráček, 2016; Smoleňová, Chrzová, 2017). A few far-right and extremist parties have been extending pro-Russian and anti-Western narratives that polarise their respective societies. While they claim to be defenders of national interests, in fact they act more like defenders of Russian politics (Čižik, 2017).

In general, the CEE states counterpropaganda actions focus on: 1) effective communication and promotion of national values, especially subjected to Russian influence, 2) strengthening independent media sector and social organisations and 3) increasing social awareness about information manipulation, disinformation and falsification. Education and information about the dangers seem to be key issues, requiring coordinated long-term actions.

Potential of future cooperation in the CEE region in the field information security. Previous means of counteracting informational threat have proven ineffective as well as their scale and scope appear inadequate to the challenge presented by the contemporary disinformation challenges in the European space. Similarly, the CEE states have failed to come up with an effective narrative to counter the Russian propaganda.

The need for coordination of actions on domestic, regional and European levels arisens. States have greater possibilities of taking specific measures within their boundaries, therefore a national strategy aimed at counteracting the immediate threats of manipulation should create favourable conditions for safeguarding the information development at national level. A growth of informational security is possible as a result of effective protection through regional cooperation and EU support as wells. International orgnisations and agencies such as the European Centre of Excellence for Countering Hybrid Threats in Finland or the NATO Strategic Communications Centre of Excellence (StratCom) Riga, play unquestionable role in preventing from the informative threats but they usually have small staff. The activities (initiating debates, proposals for resolutions) of the representatives from the CEE states in the assemblies of the Council of Europe and OSCE will also be very important. The CEE states may contribute to both abovementioned finding challenges in the information environment and improving strategic communication between the states. Moreover Poland and the Baltic states participate in the multilateral initiatives such as Nordic-Baltic-Polish cooperation in the field of hybrid threats, strengthening the 
independent media sector and social organisations as well as increasing civil awareness through education and media literacy skills.

So far the V4 states have recognized the strategic communication and partnership between CEE governments significant to launch the joint Visegrad TV project exemplified by the Quartet programme prepared and aired in all four public service TV stations of Poland, Czech Republic, Hungary and Slovakia. Each magazine deals with one main topic presented from the point of view of particular journalists from the four countries. Countries prepare their own language versions of the programme consisting of 4 shots. Quartet magazine was awarded The International Visegrad Prize in 2015 by the V4 ministries and is supported by International Visegrad Fund. On this site the audience can watch Quartet's video in 4 language versions. The Baltic states should reconsider if the abovementioned model of coopertion is suitable for them.

So far several attempts to deal with the problem of propaganda have been taken in the nongovernmental sector, both on national and regional levels. In the fight against propaganda, independent think tanks, NGOs, and civil society activists support national government legal remedies. Other activities in the non-governmental sector include workshops, roundtables, and meetings devoted to asymmetrical threats by actors operating on information security topics. Undoubtedly, the strategic communication between the officials (state level), experts, NGOs and community should be strengthened to build social capacities and resilience. Several activity should be arranged to increase this cooperation in training and education. Additionally, to counter the information risks, researchers and experts analyse and then identify and expose propaganda methods and who is behind websites or messages spreading pro-Kremlin disinformation. The lack of critical thinking, together with a combination of socio-political populism and pro-Russia business links in the CEE states, increases their vulnerabilities to risks in more areas than just information security (Hornik, 2016).

Conclusions. As Ben Nimmo noticed "the best defence against disinformation is information: that is, that disinformation is least effective in countries and communities that have access to a range of independent news and information sources" (FEPS, 2016). Estonia has already launched the new ETV+ channel that broadcasts local news to local Russian-speaking populations in Russian language. Paradoxically, as a few examples indicate, Russian-language ETV+ may not only enhance the integration of the Russianspeaking community in Estonia, but also initiate mutual communication and inspire tolerance and trust between Russians and Estonians. Research shows that Estonians watch Russianlanguage TV too (LSM, 2016). Latvia should reconsider this model for its domestic counter-propaganda solution.

It is necessary to develop effective offensive procedures to fight propaganda in the media and promote democratic values (Nimmo, 2015; Reichardt, 2016). States should strive to create an open, pluralistic information environment. Such strategies should be realized by both public and private sectors as well as the civil sector so as to cooperate in information complementation and exchange. The issue of disinformation cannot be solved by politicians and social leaders alone, but they do play a key role when it comes to answering that problem. Dealing with the contemporary challenges should include prevention, community management, social media management, psychosocial support and legal measures. Restoration of confidence in the media and development of professional journalism are essential (Zaliznyak, 2016).

Openness of the Western societies makes them vulnerable to informational threats. Ensuring informational security should not, however, incur resignation from basic democratic rules: human and civil rights, freedom of speech, law and order, pluralism and privacy.

It has been concluded that undertaking actions aiming at strengthening civil societies and improving communication and cooperation between the society and the government is of essence. A good example is a global network of (traditional and social media) editors, media executives and journalists, which aims to better understand the types of mechanism and identify best practices for preventing and better responding to contemporary challenges in an informative field.

The CEE states are influenced by the Russia's multilevel and multi-narrative propaganda (Hajduk, Stępniewski, 2015). Particularly, some parlicular political phenomenon such as elections create 
circumstanses for Russia' propaganda to work. They may provoke some fake news campaigning and inflammatory issues like immigration policies are likely to be on the table. Secondly, shaping collective historical memory is an important element of Russian foreign policy. Thus with the approach of the 75th anniversary of the end of World War II (8/9 May), Russian diplomatic and propaganda attacks in the post communist space will continue. Under those circumstances the CEE region must stand together and jointly counter disinformation disseminating across the border.

\section{Bibliography}

1. Čižik T. (2017). Russian Information Warfare in Central Europe. In Čižik T. (ed.), Information Warfare - New Security Challenge for Europe, Bratislava: Centre for European and North Atlantic Affairs, 8-31.

2. Hajduk J., Stępniewski T. (2015). Wojna hybrydowa Rosji z Ukraina: uwarunkowania $i$ instrumenty [Russia's hybrid war with Ukraine: conditions and instruments]. Studia Europejskie, 4(76), $135-151$.

3. Hornik, R. (2016). A strategy to counter propaganda in the digital era. Yearbook of the Institute of East-Central Europe, 14(2), 61-74.

4. Jiráček, L. (2016, December). Soft risks and threats to safety and security: the case of the Czech Republic. In. A. Visvizi, T. Stępniewski (Eds.), Poland, the Czech Republic and NATO in Fragile Security Contexts, IESW Reports, 64-67.

5. LSM (2016, February 11). Глава русскоязычного ТВ Эстонии: доверие зрителя пришло не cpasy' [The head of the Russian-speaking Estonian TV: the viewer trust did not come immediately]. LSM. LV, http://www.lsm.lv/ru/statja/obschestvo/novosti/glava-russkojazichnogotv-estonii-doverie-zriteljaprishlo-ne-srazu.a168679/ (2020-01-30).

6. Milo D., Klingová K. (2017). The Vulnerability Index: Subversive Russian Influence in Central Europe, GLOBSEC Report. Budapest: Globsec Policy Institute.

7 Nimmo B. (2015, May 19). Anatomy of an Info-War: How Russia's Propaganda Machine Works, and How to Counter It, StopFake.org, https://www.stopfake.org/en/anatomy-of-an-info-war-how-russia-spropaganda-machine-works-and-how-to-counter-it (2020-02-11).

8. Reichardt I. (2016). Russian propaganda in the West. Yearbook of the Institute of East-Central Europe, 2016, 14(2), 9-22.

9. FEPS. (2016). Resisting Foreign State Propaganda in the New Information Environment: the case of the EU, Russia, and the Eastern Partnership countries, Foundation for European Progressive Studies - Brīivibas un Solidaritātes Fonds.

10. Smoleňová I., Chrzová B. (eds., 2017, November). United We Stand, Divided We Fall: The Kremlin's Leverage in the Visegrad Countries. Prague: Prague Security Studies Institute (PSSI).

11. Šuplata M. , Nič M. (2016), Russia's information Was in Central Europe: new trends and counter-measures, GLOBSEC Report, Bratislava: GLOBSEC Policy Institute.

12. Zaliznyak, Y. (2016). Information security and Russian aggression: Ukraine-EU-NATO hybrid response. Yearbook of the Institute of East-Central Europe, 14(2). 23-42. 